\title{
Autoantibodies in Indian-Asians with insulin-dependent diabetes in the UK
}

\author{
O. Odugbesan, ${ }^{1}$ J.A. Fletcher, ${ }^{1}$ A. Sanders, ${ }^{3}$ A.R. Bradwell, ${ }^{2}$ G.F. Botazzo ${ }^{3}$ and \\ A.H. Barnett ${ }^{1}$ \\ Departments of ${ }^{1}$ Medicine and ${ }^{2}$ Immunology, University of Birmingham and East Birmingham Hospital, \\ Birmingham, and ${ }^{3}$ Department of Immunology, Middlesex Hospital Medical School, London ${ }^{3}, U K$.
}

\begin{abstract}
Summary: Classical insulin-dependent diabetes mellitus (IDDM) is relatively uncommon in Indian-Asians whether in India or in the UK and this may be related to immunogenetic factors. We have studied the presence or absence of islet cell antibodies and other auto-antibodies in 36 subjects with IDDM and 41 controls, all of Indian origin. Islet cell antibodies (ICA-IgG) were found in 8 subjects with IDDM but in none of the controls. Four of the 8 patients with ICA-IgG also possessed the complement fixing variety (CF-ICA). There was no definite association between possession of ICA and HLA-DR antigens. Thyroid antibodies were commoner in patients (22\%) compared with controls $(7 \%)$ as were parietal cell antibodies $(8.3 \%$ vs $4.8 \%)$. None of the patients or controls had adrenal antibodies.

The frequency of organ-specific antibodies in Indian-Asians with IDDM is similar to that of white Caucasians. The overall frequency of ICA is, however, lower than that reported for white Caucasians although the temporal distribution is similar. We conclude that even though the prevalence of IDDM in Indian-Asians is lower than in white Caucasians there is no evidence that different immunological mechanisms are involved in the pathogenesis of IDDM in the two groups.
\end{abstract}

\section{Introduction}

There is good evidence that autoimmune mechanisms are involved in the pathogenesis of insulin-dependent diabetes mellitus (IDDM). Studies of white Caucasians have established the association between IDDM and HLA antigens DR3 and DR4 as well as the presence of islet cell and other organ-specific autoantibodies. ${ }^{1-3}$ The few studies in other racial groups have suggested some heterogeneity of the autoimmune association with IDDM. For example, Americal Black and Japanese populations with IDDM have a reduced propensity to pancreatic autoimmunity, ${ }^{4,5}$ in comparison with white Americans and Europeans.

The Asian community in the UK consists mainly of immigrants from the Indian subcontinent. Previous studies have suggested that this population has a lower frequency of classical IDDM $^{6,7}$ but an overall much higher prevalence of non-insulindependent diabetes (NIDDM) ${ }^{7}$ in comparison with

Correspondence: A.H. Barnett, M.D., M.R.C.P., Department of Medicine, East Birmingham Hospital, Bordesley Green East, Birmingham, UK.

Accepted: 16 December 1987 the indigenous white population. Recent studies from our group have suggested that this low frequency of IDDM may be related to genetic differences in the Indian-Asian population. ${ }^{8} \mathrm{We}$ have now studied the prevalence of islet cell, thyroid, gastric parietal cell and adrenal antibodies in Indian-Asians with IDDM and racially matched controls and related these to HLA-DR antigen frequencies.

\section{Patients and methods}

Subjects with IDDM attending 7 diabetic clinics in the West Midlands were studied. IDDM was defined as ketosis prone diabetes with acute onset of symptoms, absolute requirement for insulin from diagnosis and age of onset less than 30 years. Healthy racially matched control subjects with no family history of diabetes were recruited from antenatal clinics and community centres. In all cases the subject or both parents were of Punjabi (Indian) origin.

(C) The Fellowship of Postgraduate Medicine 1988 
Thirty-six subjects with IDDM and 41 control subjects were studied. Conventional islet cell antibodies (ICA-IgG) were detected by indirect immunofluorescence (IFL) on unfixed blood group $O$ human pancreas obtained from cadaver kidney donors. ${ }^{9}$ Complement-fixing islet cell antibodies (CF-ICA) were assayed by the IFL complementfixation test. ${ }^{9}$ Both tests are included and validated in an ongoing International Programme for the standardization of cytoplasmic ICA. ${ }^{10}$

Gastric parietal cell and adrenal antibodies were determined by IFL on human substrates, and thyroid microsomal and thyroglobulin antibodies by haemagglutination with commercial kits (Wellcome). ${ }^{11}$ HLA-DR antigens $1-5$ and 7 were identified by a standard microlymphocytotoxicity method using commercially prepared typing trays (BIOTEST). ${ }^{12}$ HLA-DR antigens were examined in 33 Indian-Asians with IDDM and 41 racially matched controls with no family history of diabetes.

\section{Results}

The mean \pm s.d. age of the patients was $19 \pm 10.7$ (range 5-40 years) and duration of diabetes was $6.2 \pm 4.6$ (range $0.4-14$ years). The mean age of the controls was $28.4 \pm 8.4$ (range $17-73$ years).

\section{Islet cell antibodies}

Eight of the 36 subjects with IDDM $(22 \%)$ had conventional ICA (ICA-IgG). Four of the 8 patients with IDDM and ICA-IgG also had CFICA. In comparison none of the controls had either ICA-IgG or CF-ICA. Four of 10 patients studied within a year of diagnosis had positive ICA-IgG and 3 of these also fixed complement (Figure 1). Three of the thirteen patients with a duration of more than 5 years had positive ICA-IgG but none of these had the complement-fixing variety.

HLA-DR antigen frequency data was available in 33 subjects with IDDM and 41 controls. Four of the eight patients with ICA-IgG possessed HLADR4, one patient who had positive ICA-IgG and CF-ICA had neither HLA-DR3 nor -DR4 (Table I). Two of the three patients with persistent ICA over 5 years after diagnosis were HLA-DR3/DR4, the third being HLA-DR3. The results of HLA-DR antigen frequency indicate a strong positive association between HLA-DR3 and IDDM (relative risk, RR, 9.6), with a weaker but positive association with HLA-DR4 ( $R R=4.7)$, and a negative association with HLA-DR2 $(R R=0.11)$ (details given in reference 8).

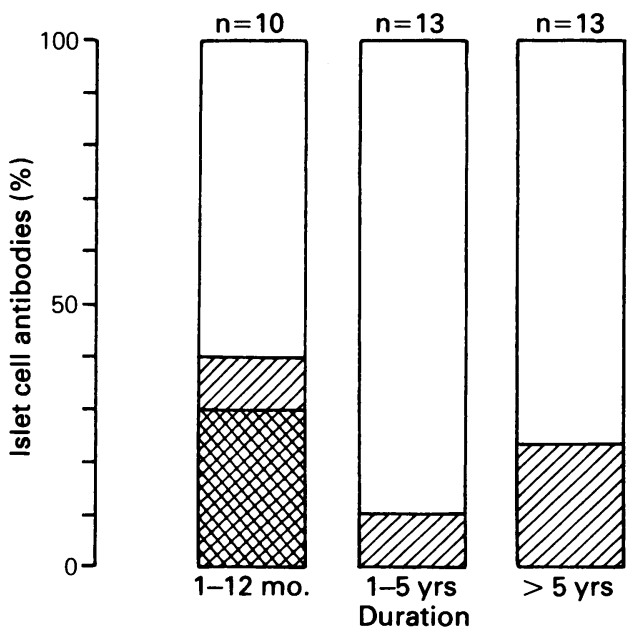

Figure 1 Frequency of islet cell antibodies according to duration of insulin-dependent diabetes in IndianAsians. Eight subjects had conventional ICA-IgG (hatched areas) and four of these also had complement fixing ICA (double hatched areas).

Table I HLA-DR antigen and islet cell autoimmunity in Indian-Asian insulin-dependent diabetes

\begin{tabular}{|c|c|c|c|c|}
\hline & \multicolumn{2}{|c|}{$\begin{array}{l}\text { ICA positive } \\
(\text { Total }=8)\end{array}$} & \multicolumn{2}{|c|}{$\begin{array}{l}\text { ICA negative } \\
(\text { Total }=25)\end{array}$} \\
\hline & No. & $(\%)$ & No. & $(\%)$ \\
\hline DR1 & 1 & (13) & 0 & (0) \\
\hline DR2 & 0 & (0) & 1 & (4) \\
\hline DR3 & 5 & (63) & 20 & (80) \\
\hline DR4 & 4 & (50) & 5 & (20) \\
\hline DR5 & 0 & $(0)$ & 4 & (16) \\
\hline DR7 & 0 & (0) & 3 & (12) \\
\hline
\end{tabular}

No. $=$ number of patients with appropriate DR antigen; ICA $=$ islet cell antibodies.

\section{Other autoantibodies}

Thyroid antibodies were detected in 8 patients $(22 \%)$ and 3 controls $(7 \%)$ (Table II). Two of the three controls with thyroid antibodies were females, and all patients with thyroglobulin antibodies were female. HLA-DR antigen frequency was available for 6 of 8 subjects with IDDM with thyroid antibodies. Three of these 6 had HLA-DR4 and the other three were HLA-DR3. Gastric parietal cell antibody was detected in three of 36 subjects with IDDM $(8.3 \%)$ and two of 41 controls $(4.8 \%)$ (Table II). Adrenal antibodies were found in neither patients nor controls. 
Table II Organ-specific antibodies in 36 Indian-Asians with insulin-dependent diabetes and 41 racially matched controls

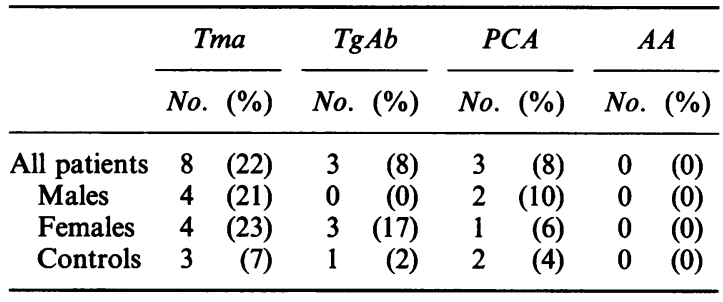

Tma = thyroid microsomal antibody; $\mathrm{TgAb}=$ thyroglobulin antibody; $\mathrm{PCA}=$ parietal cell antibody; $\mathbf{A A}=$ adrenal antibody.

\section{Discussion}

Studies in European and North American white Caucasian populations have shown that the prevalence of ICA in patients with IDDM is about $36 \% .^{4}$ In these populations the prevalence of ICA is about $60 \%$ at diagnosis falling to $45 \%$ within a year and $25 \%$ five years after the diagnosis of IDDM.

The overall prevalence of ICA in Indian-Asian subjects with IDDM in this study is lower than that found in the indigenous white Caucasian populations at $22 \%$. It is, however, similar to the prevalence of ICA in US Blacks ${ }^{4}$ a population with a lower frequency of IDDM than US Whites. $\mathrm{We}^{6}$ and others ${ }^{7}$ have previously reported that the Indian-Asian community in the UK have a lower frequency of IDDM compared with the indigenous UK Whites and within this group of Asian diabetics this frequency of islet cell autoimmunity may also be lower. There is still controversy as to the frequency of IDDM in Asians in the UK, ${ }^{13}$ but taken with the data from the Indian subcontinent ${ }^{14}$ the lower frequency compared with white Caucasians is probably genuine.

While the overall prevalence of ICA in IndianAsians is lower, the time course for persistence of ICA is similar to that found in white IDDM populations ${ }^{4}$ with $40 \%$ of patients possessing ICA within a year of diagnosis and $23 \%$ with ICA five years after diagnosis.

IDDM in European Caucasian and North American populations is associated with possession of either or both HLA-DR3 and -DR4. ${ }^{3}$ We have found a similar association in this racial group though, unlike in Europeans and North Americans, DR3 is the major genetic susceptibility factor with DR4 being more weakly associated. ${ }^{8}$ No firm conclusions can be drawn about the association between islet cell antibody and HLA-DR types in this population, but it may be of interest that, of 8 patients with positive ICA, 4 possessed HLA-DR4 whilst of 25 subjects with IDDM without ICA only 5 possessed DR4. The four DR4 patients with positive ICA all had duration of IDDM of 1 year or more. This may indicate that possession of DR4 leads to higher risk of islet cell autoimmunity in Indian-Asian subjects with IDDM as opposed to European Caucasian populations where DR3 is associated with persistent islet cell autoimmunity.

Previous studies in Indian-Asians in the Indian subcontinent ${ }^{15,16}$ and South Africa ${ }^{17}$ suggest that islet cell autoimmunity is somewhat less common in this population both in terms of total prevalence or time course. Only one study ${ }^{14}$ examined the association between HLA-DR antigen types and islet cell autoimmunity, but no association between any particular DR antigen type and islet cell autoimmunity at diagnosis or persistence after 5 years duration of IDDM was found. The DR antigen frequency data in this study, however, suggested no association between IDDM and DR4, with a high percentage of the control population possessing this antigen, which is at variance with our own results. ${ }^{8}$

The presence of other organ-specific autoantibodies in patients with IDDM has been reported in many studies. In our study the IndianAsian patients with IDDM showed higher levels of thyroid and gastric parietal cell antibodies than controls though none of the subjects with IDDM or controls had adrenal antibodies. The levels of thyroid and gastric parietal cell autoimmunity in the Indian subjects with IDDM is similar to that found in Caucasian populations with IDDM and higher than that found in US Blacks ${ }^{4}$ though there was a total absence of adrenal antibodies. Our results are also similar to those reported in other IndianAsian groups. ${ }^{15,16}$ In the white Caucasian populations with IDDM thyroid autoimmunity is commoner in females and in our study such an association has been found in the levels of thyroglobulin antibodies. The frequency of organspecific antibodies in Indian-Asians with IDDM seems to be similar to that in white Caucasian subjects with IDDM apart from the differences found in the ICA frequency and HLA-DR antigen susceptibility pattern. This may suggest that organspecific autoimmunity is inherited separately from immunogenetic susceptibility to IDDM. ${ }^{18}$

We have found no evidence to suggest that immunological mechanisms involved in pathogenesis of IDDM in Indian-Asians is different from that of white Caucasians but our observations highlight ethnic variability in the immunogenetic associations of insulin-dependent diabetes in different racial groups. 


\section{Acknowledgements}

The authors are grateful to Dr R. Thompson, Regional Department of Immunology, East Birmingham Hospital, for measurements of gastric parietal cell and adrenal antibodies.

\section{References}

1. Bottazzo, G.F., Florin-Christensen, A. \& Doniach, D. Islet cell antibodies in diabetes mellitus with autoimmune polyendocrine deficiencies. Lancet 1974, ii: $1279-1282$.

2. Christy, M., Deckert, T. \& Nerup, J. Immunity and autoimmunity in diabetes mellitus. Clin Endocrinol Metab 1977, 6: 205-332.

3. Wolf, E., Spencer, K.M. \& Cudworth, A.G. The genetic susceptibility to type 1 (insulin-dependent) diabetes: analysis of the HLA-DR association. Diabetologia 1983, 24: 224-230.

4. Neufeld, M., MacLaren, N.K., Riley, W.J. et al. Islet cell and other organ specific antibodies in US Caucasians and Blacks with insulin dependent diabetes mellitus. Diabetes 1980, 29: 589-592.

5. Kanazawa, Y. Some genetic and immunological aspects of type 1 (insulin-dependent) diabetes in Japan. In: Adreani, D., DiMario, U., Federlin, K.F. \& Heding, L.G. (eds) Immunology in Diabetes. Kimpton Medical, London, 1984, pp 159-169.

6. Odugbesan, O. \& Barnett, A.H. Asian patients attending a diabetic clinic. $\mathrm{Br}$ Med J 1985, 290: 10511052.

7. Mather, H.M. \& Keen, K. The Southall Diabetes Survey: prevalence of known diabetes in Asians and Europeans. $\mathrm{Br}$ Med J 1985, 290: 1081-1084.

8. Odugbesan, O., Fletcher, J., Mijovic, C., MacKay, E., Bradwell, A.R. \& Barnett, A.H. The HLA-D associations of Type 1 (insulin dependent) diabetes in Punjabi Asians in the United Kingdom. Diabetologia 1987, 30: 618-621.

9. Bottazzo, G.F., Pujol-Borrell, R. \& Doniach, D. Humoral and cellular immunity in diabetes mellitus. Clinics Immunol Allerg 1981, 1: 139-159.

10. Bottazzo, G.F. \& Gleichman, H. Immunology and Diabetes Workshops. Report of the first International Workshop on the standardisation of cytoplasmic islet cell antibodies. Diabetologia 1986, 28: 125-126.
Ola Odugbesan is supported by Novo, Jeremy Fletcher is supported by the Medical Research Council.

11. Schezbaum, W.A., Kizokian, R., Pujol-Burrell, R., Dean, B.M. \& Bottazzo, G.F. Immunocytochemistry in the study and diagnosis of organ-specific autoimmune disease. In: Polak, J.M. \& Van Norden, S. (eds) Immunocytochemistry, Modern Methods and Applications. J. Wright and Sons, Bristol, 1986, pp 456-476.

12. Tait, B.D. \& Simons, M.J. Serological detection of HLA-D locus related (DR) gene products. In: Simons, M.J. \& Tait, B.D. (eds) Detection of Immune Associated Genetic Markers of Human Disease. Churchill Livingstone, London, 1984, pp 37-45.

13. Samanta, A., Burden, A.C. Jones, G.R. et al. Prevalence of insulin dependent diabetes mellitus in Asian children. Diabetic Medicine 1987, 4: 65-67.

14. Odugbesan, O. \& Barnett, A.H. Immunogenetics of insulin dependent diabetes - racial differences. In: Barnett, A.H. (ed) Immunogenetics of Insulin Dependent Diabetes. MTP Press, 1987, pp. 90-100.

15. Ramachandran, A., Rosenbloom, A.L., Mohan, V. et al. Autoimmunity in South Indian patients with IDDM. Diabetes Care 1986, 9: 435.

16. Bhatia, E., Melira, N.K., Taheja, V., Vaidya, M.C. \& Ahuja, M.M.S. HLA-DR antigen frequencies in a north Indian type 1 diabetic population. Diabetes 1985, 34: 565-567.

17. Omar, M.A.K., Bottazzo, G.F. \& Asmal, A.C. Islet cell antibodies and other autoantibodies in South African blacks and Indians with insulin dependent diabetes mellitus (IDDM). Horm Metab Res 1980, 18: 126-128.

18. Gorsuch, A.N., Dean, B.M., Bottazzo, G.F., Lister, J. \& Cudworth, A.G. Evidence that type 1 diabetes and thyrogastric autoimmunity have different genetic determinants. Br Med J 1980, 280: 145-147. 